28. Классификация и диагностика почв СССР / сост. В.В. Егоров, Е.Н. Фридланд, Е.Н. Иванова, Н.Н. Розов, В.А. Носин, Т.А. Фриев. М.: Колос, 1977. 224 с.

29. Раменский Л.Г., Цаценкин И.А., Чижиков О.Н., Антипин Н.А. Экологическая оценка кормовых угодий по растительному покрову. М.: Сельхозгиз, 1956. $472 \mathrm{c}$.

30. Зверев А.А. Информационные технологии в исследованиях растительного покрова: учебн. пособие. Томск: ТМЛ-Пресс, 2007. 304 с.

31. Демина О.Н. Классификация растительности степей Дона: монография // Ростов-на-Дону: Изд-во Южного федерального университета, 2015. 212 с.

32. Винокуров Д.С. Синтаксономія ксеротермної рослинності долини р. Інгул (клас Festuco-Brometea). Частина 1. Петрофітно-степова рослинність) // Ukrainian Botanical Journal. 2014. № 71 (2). C. 148-160.

33. Королюк А.Ю. Степи Северного Казахстана синтаксономическая ревизия // Растительность России. 2017. № 30. С. 61-77.
34. Ямалов С.М., Баянов А.В., Мартыненко В.Б., Мулдашев А.А., Широких П.С. Эндемичные ассоциации петрофитных степей палеорифов Южного Урала // Растительность России. 2011. № 19. С. 117-126.

35. Королюк А.Ю. Степная растительность (Festuco-Brometea) предгорий Западного Алтая // Растительность России. 2007. № 10. С. 38-60.

36. Зеленая книга Самарской области: редкие и охраняемые растительные сообщества / под ред. Г.С. Розенберга, С.В. Саксонова. Самара: СамНЦ PAH, 2006. $201 \mathrm{c}$.

37. Красная книга Самарской области. Т. 1. Редкие виды растений и грибов / под ред. С.А. Сенатора и С.В. Саксонова. Самара: Изд-во Сам. государственной областной академии (Наяновой), 2017. 384 с.

Исследования проведены в рамках бюджетных тем БИН РАН № АAAA-A17-117071760037-0 и ИЭВБ РАН № АAAA-A17-117112040040-3. Автор благодарит РФФИ за финансовую поддержку исследований (проект 16-04-00747a).

\title{
STEPPE COMMUNITIES IN THE VICINITY OF TOGLIATTI (SAMARA REGION)
}

(C) 2018

Lysenko Tatyana Mikhaylovna, doctor of biological sciences,

leading researcher of General Geobotany Laboratory; leading researcher of Phytodiversity Problems Laboratory

Komarov Botanical Institute of Russian Academy of Sciences (Saint Petersburg, Russian Federation);

Institute of Ecology of the Volga River Basin of Russian Academy of Sciences

(Togliatti, Samara Region, Russian Federation)

Abstract. The paper describes the study of steppe vegetation in the Samara Region. It contains results of the steppe communities field study conducted in 2014-2015 in the vicinity of Togliatti (Samara Region). Geobotanical relevès were made on standard sites for steppe vegetation. Projective covering of plant species in field conditions was estimated as a percentage and then converted to scores using B.M. Mirkin's scale. The relevès are placed in the geobotanical database «Vegetation of the Volga and Ural Basins» and processed using the computer program JUICE. Bioindication studies were conducted using the IBIS program. As a result of the syntaxonomic analysis carried out using the floral approach to the classification of vegetation by J. Braun-Blanquet, 2 new associations and 6 new subassociations were identified. Their names are given in accordance with the «International Code of Phytosociological Nomenclature». Their position in the system of higher syntaxons of Europe is established, nomenclature types, diagnostic types are given, composition and structure, ecology and distribution of communities are characterized as well as the results of processing according to the scales by L.G. Ramensky. The communities of all established syntaxons are recommended for inclusion in the $2^{\text {nd }}$ edition of the «Green Book of the Samara Region».

Keywords: steppe community; coenosis; meadow steppe; psammophytic edaphic variant; syntaxonomy; floristic classification; association; subassociation; nomenclature type; diagnostic species; ecological scale; rare plant community; Togliatti; Samara Region.

\section{УКОРЕНЕНИЕ МИКРОЧЕРЕНКОВ VACCINIUM CORYMВOSUM L. СОРТА БЛЮ БЕРРИ В КУЛЬТУРЕ IN VITRO И ЕX VITRO}

\author{
Мохамед Гамил Райян Абуэлдис, аспирант кафедры ботаники и физиологии растений \\ Хуснетдинова Ландыш Завдетовна, кандидат биологических наук, \\ доцент кафедры ботаники и физиологии растений \\ Тимофеева Ольга Арнольдовна, доктор биологических наук, \\ профессор кафедры ботаники и физиологии растений \\ Казанский (Приволжский) федеральный университет (2. Казань, Российская Федерация)
}

\footnotetext{
Аннотация. В данной статье рассматривается вопрос клонального микроразмножения Vaccinium corymbosum L. сорта Блю Берри, который позволяет на основе приемов культуры изолированных тканей и органов in vitro ускорить получение растения генетически идентичные исходным. Показано, что микроразмножение пазушных побегов голубики высокорослой было более эффективным на WPM с добавлением 1,0 мг/л зеатина и 0,1 мг/л индолил-3-масляной кислоты. В течение пяти пассажей было показано, что максимальное увеличение количества здоровых пазушных побегов наблюдается на четвертом пассаже, тогда как
} 
Мохамед Г.Р.А., Хуснетдинова Л.З., Тимофеева О.А

с пятого пассажа начинает появляться феномен гипергидратации (витрификации). Установлено, что присутствие в составе питательной среды индолил-3-масляной кислоты и 1,0 г/л активированного угля приводило к хорошему формированию корневой системы голубики высокорослой. Наибольшее среднее количество сформированных корней на эксплантат было получено на среде WPM, дополненной 0,5 мг/л индолил-3масляной кислотой через 10 недель. Акклиматизация растений-регенерантов $V$. corymbosum, имеющих развитую корневую систему, при переносе в естественные условия ex vitro (pH 3,5-4) показала 100\% выживаемость.

Ключевые слова: Vaccinium corymbosum L.; голубика высокорослая; растения-регенеранты; in vitro; ex vitro; эксплант; сегменты стебля; среда WPM; апикальные части стебля; микроклональное размножение; сорт Блю Берри; адаптация; ризогенез; укоренение; биологические ресурсы.

\section{Введение}

Голубика высокорослая, имеющая высокое антиоксидантное действие, представляет собой особую ценность как пищевой продукт и лекарственное растительное сырье $[1$, с. 39-43; 2, с. 2714-2719; 3, с. $637-643 ; 4$, с. $45-48]$. Традиционно голубику размножают классическими методами вегетативного размножения, т.е. зелеными и одревесневшими черенками, а также отводками. Однако успешному применению этих методов препятствуют некоторые ограничения. Так, например, размножение черенками - относительно простой метод, но укоренение не всегда бывает удовлетворительным и часто требует применения регуляторов роста. Этот метод размножения трудоемок и требует значительной площади [1, с. 39-43; 3, с. 637-643; 5, с. 96-103; 6, p. 327-332].

В настоящее время получение в промышленных масштабах генетически однородного посадочного материала, сохраняющего свойства материнского растения, является одной из важных задач растениеводства. Использование современных биотехнологических подходов позволяет решить данную проблему, а метод клонального микроразмножения позволяет увеличить коэффициент размножения до сотен, тысяч и даже миллионов растений в год с одного растения. Микроклональное размножение считается альтернативным методом вегетативного размножения и является экономически выгодным [5, с. 96103 ; 7, с. $5-9 ; 8$, с. 104-107; 9, с. 286-288]. Кроме того, этот метод позволяет ускоренно размножать новые перспективные культуры, получать здоровый растительный материал, работать в лаборатории круглый год и планировать выпуск посадочного материала к определенному сроку $[1$, с. $39-43$; 3 , c. 637-643; 10, с. 37-39]. Важным этапом клонального микроразмножения является этап укоренения размноженных микропобегов in vitro, поскольку каждый вид и сорт растений предъявляет свои требования к условиям выращивания с их последующей адаптацией к естественным условиям среды.

Основной целью исследований являлось изучение эффективности влияния различных регуляторов роста на ризогенез Vaccinium corymbosum L. сорта Блю Берри в культуре in vitro и дальнейшей адаптации растений в условиях ex vitro.

\section{Материал и методика исследований}

Объектом для введения в культуру in vitro явились саженцы голубики высокорослой сорта Блю Берри полученные от компании Bekker в Казахстане. В качестве эксплантов использовали различные части растений - апикальные части стебля и сегменты стебля, взятые с саженцев (рис. 1).

Предварительная стерилизация первичных эксплантов проводилась путем промывания в мыльной воде, с последующей отмывкой стерильной водой.
Обработка первичного растительного материала проводилась $15 \%$ раствором коммерческого отбеливателя «Белизна» $(5,25 \%$ гипохлорида натрия $\mathrm{NaOCl})$, с добавлением нескольких капель $0,1 \%$ «Твин-80» с экспозицией 10 и 15 минут.

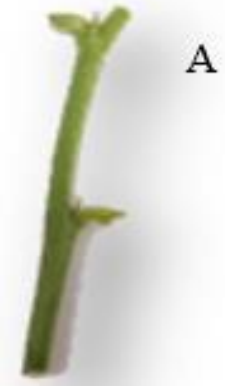

A

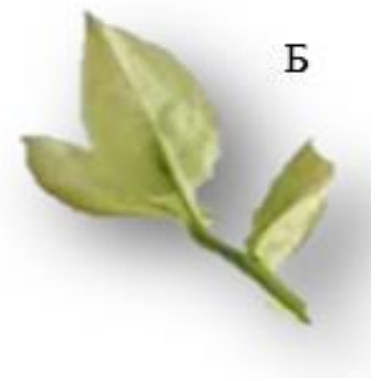

Рисунок 1 - Типы эксплантов:

\section{$A$ - сегменты стебля; 5 - апикальные части стебля}

После стерилизации экспланты были высажены на твердую базовую среду WPM [11, p. 421-427] с добавлением 1,0 мг/л зеатина (Зе) и 0,1 мг/л индолил-3-масляной кислоты (ИМК) [12, р. 40-44; 13, p. 233-240; 14, p. 294-304], 100 мг/л миоинозитола, 25 г/л сахарозы и 2,7 г/л фитагеля. Высаженные экспланты выращивались in vitro при искусственном освещении (3000 Люкс) в условиях фотопериода: $16 / 8$ ч. свет/темнота и температуре воздуха $26 \pm 2{ }^{\circ} \mathrm{C}$.

Микрочеренки, полученные на этапе собственно микроразмножения, в дальнейшем были перенесены на этап укоренения. В качестве индукторов ризогенеза были использованы ауксины: ИМК в концентрациях $(0,5 ; 1,0 ; 2,0$ мг/л) и $\beta$-индолилуксусная кислота (ИУК) в концентрациях 0,5 и 1,0 мг/л. Через десять недель культивирования были учтены следующие показатели: укоренившиеся экспланты (\%), количество корней/эксплант (шт.), средняя длина корней (см).

Растения-регенеранты, имеющие развитую корневую систему, были перенесены в естественные условия ex vitro для адаптации. Экспланты, не имеющие корневой системы, были предварительно обработаны раствором ИМК в различных концентрациях (1,0 и 2,0 г/л) с экспозицией 5 и 10 минут и тоже перенесены в условия грунта.

Для адаптации растений-регенерантов голубики в качестве субстрата использовали почву (BONA FORTE, pH 3,5-4). Высаженные растения сверху накрывали пластиковыми колпачками и переносили в теплицу (температура $25 \pm 1{ }^{\circ} \mathrm{C}$, относительная влажность 80-90\%). Через 30 дней растения-регенеранты пересаживали в горшки большего размера диаметром 12 см и выращивали на открытом воздухе. Период акклиматизации составлял 60-90 дней. Процент выживших растений-регенерантов регистрировали через 90 дней (рис. 2). 


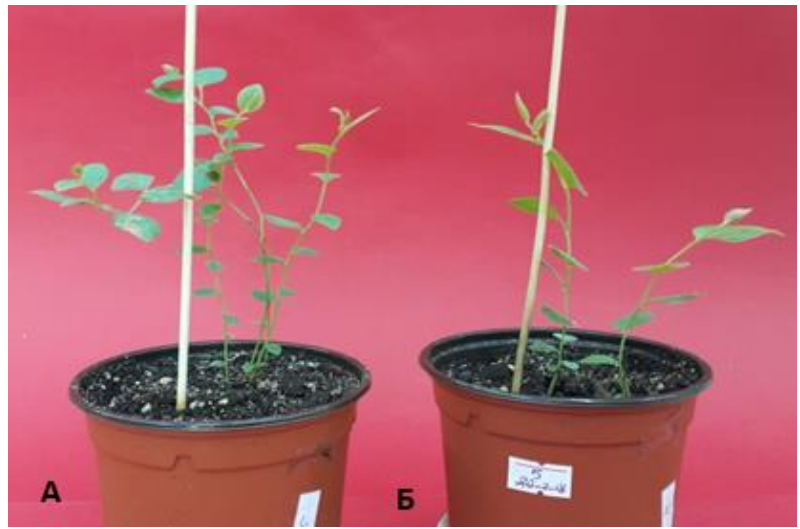

Рисунок 2 - Акклиматизированные растениярегенеранты голубики высокорослой сорта Блу Берри: $A$ - имеющие развитую корневую систему; 5 - не имеющие корневой системы

\section{Результаты исследований и их обсуждение}

Исследования показали, что использованный метод поверхностной стерилизации эксплантов оказался приемлемым и эффективным. При применении стерилизующего агента $10 \%$ раствора коммерческого отбеливателя «Белизна» $(5,25 \% \mathrm{NaOCl})$ с экспозицией 10 минут выживаемость апикальной части стебля составила 90\%. Наиболее высокие показатели выживаемости $(100 \%)$ сегментов стебля асептической культуры голубики были получены при использовании метода стерилизации с применением $15 \%$ раствора отбеливателя «Белизна» в течение 15 минут.

Микропобеги, развившиеся в культуре, переносили на свежие питательные среды. Микроразмножение пазушных побегов голубики высокорослой было более эффективным на WPM с добавлением 1,0 мг/л Зе и 0,1 мг/л ИМК. Сегменты стебля с пазушными почками были использованы в последующих экспериментах. В течение пяти пассажей было показано, что максимальное увеличение количества здоровых пазушных побегов наблюдается на четвертом пассаже. Среднее количество пазушных побегов на эксплант составило 5,3 шт./эксплант со средней длиной 3,32 см. С пятого пассажа начинает появляться феномен гипергидратации (витрификации).

Важным этапом микроразмножения является укоренение полученных микрочеренков. Как известно, для эффективного укоренения микрочеренков в качестве индуктора ризогенеза применяют ауксин с подбором оптимальных его концентраций $[15$, с. $21-$ 25]. Нами было изучено влияние различных ауксинов: ИМК в концентрациях 0,$5 ; 1,0$ и 2,0 мг/л; ИУК в концентрациях 0,5 и 1,0 мг/л и их комбинаций на укоренение полученных регенерантов $V$. corymbosum сорта Блю Берри в культуре in vitro.

Наиболее часто применяемым ауксином для стимуляции ризогенеза растений является ИМК. Он оказался наиболее эффективным для укоренения побегов таких культур, как Vaccinium corymbosum, Fragaria $\times$ ananasa, Grossularia и многих других [16, p. $144-146 ; 17$, с. $22-30 ; 18$, p. $169-176 ; 19$, с. $25-28$; 20 , с. 246]. В результате наших исследований установлено, что присутствие в составе питательной среды 0,5 мг/л ИМК и 1,0 г/л активированного угля приводило к хорошему формированию корневой системы голубики высокорослой сорта Блю Берри через десять недель (рис. 3).

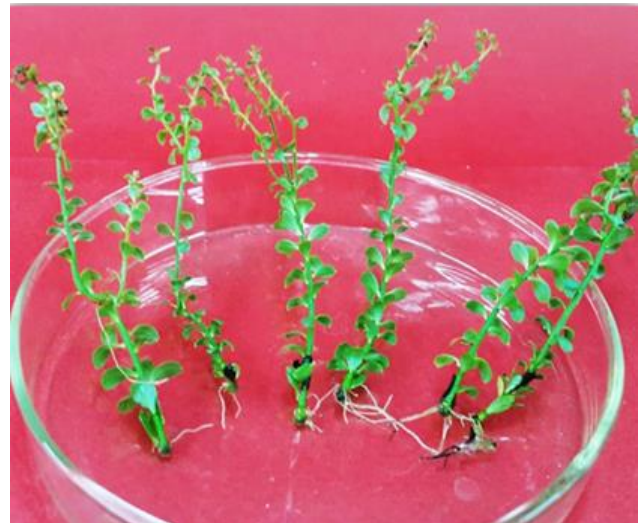

Рисунок 3 - Влияние ИМК (0,5 мг/л) на укоренение микрочеренков голубики сорта Блю Берри

На данной среде наблюдали наиболее высокие показатели (90\%) укоренившихся эксплантов (рис. 4): количество корней/эксплант составило 4,4 шт. со средней длиной корней/эксплант 1,05 см по сравнению с контрольным вариантом (рис. 5).

В основе клонального микроразмножения растений лежат два принципиально разных этапа: in vitro u ex vitro. После переноса регенерантов из условий in vitro начинается второй этап жизнедеятельности регенерантов в системе ex vitro, то есть в условиях открытого грунта, совершенно отличных от условий in vitro. В условиях ex vitro растения вынуждены перейти с гетеротрофного типа питания на автотрофный. Важным этапом при получении размноженных растений-регенерантов является укоренение микропобегов in vitro. Слабо развитая корневая система в последующем отрицательно отражается на способности растений адаптироваться и выживать в условиях ex vitro. Как известно, в процессах индукции ризогенеза главная роль отводится эндогенному соотношению ауксинов [4, с. 45-48]. Для адаптации растений $V$. corymbosum полученные растения-регенеранты, имеющие развитую корневую систему, были перенесены в естественные условия ex vitro. Выход растений голубики высокорослой адаптированных к условиям выращивания ex vitro составил $100 \%$ (рис. 6,7$)$.

Экспланты, не имеющие корневой системы, были предварительно обработаны ИМК в различных концентрациях (1,0 и 2,0 г/л) с экспозицией 0,5 и 10 минут и тоже перенесены в условия грунта. Количество выживших растений-регенерантов (\%) увеличилось с $60 \%$ (контрольный вариант) до 80\% (обработанные варианты) (рис. 8).

\section{Выводы}

В результате наших исследований показана возможность укоренения микрочеренков Vaccinium corymbosum L. сорта Блю Берри в культуре in vitro и ex vitro. Для получения высокого коэффициента укоренения растений in vitro наиболее эффективным индуктором ризогенеза является ИМК в концентрации 0,5 мг/л, что позволяет укоренить до 90\% микрочеренков голубики. Все растения-регенеранты, полученные in vitro, успешно проходят период адаптации к условиям выращивания ex vitro. У эксплантов, не имеющих корневой системы, показана возможность укоренения ex vitro после дополнительной обработки ИМК в концентрации 1 мг/л с экспозицией 5 минут, в результате чего $80 \%$ растений проходят укоренение. Таким образом, данное исследование представляет научный интерес и может использоваться в целях крупномасштабного производства Vaccinium corymbosum $\mathrm{L}$. 


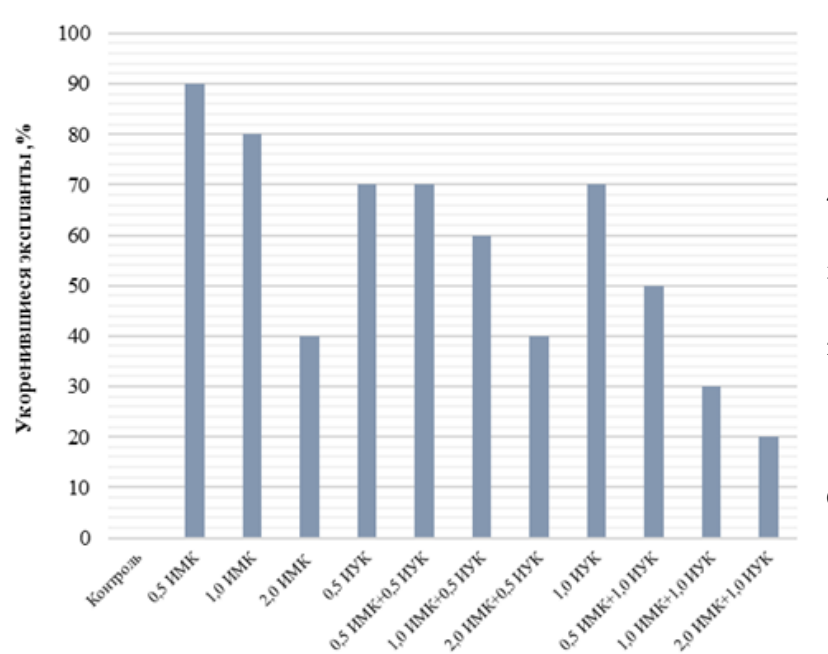

Рисунок 4 - Укоренившиеся экспланты (\%)

V. corymbosum сорта Блю Берри

на питательной среде WPM,

дополненной различными концентрациями ауксина

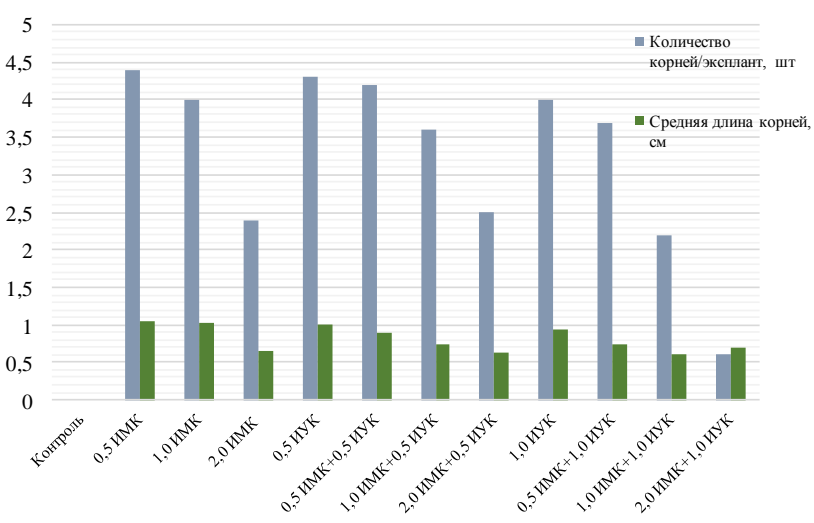

Рисунок 5 - Влияние различных концентраций ауксина на укоренение микрочеренков голубики сорта Блю Берри через десять недель

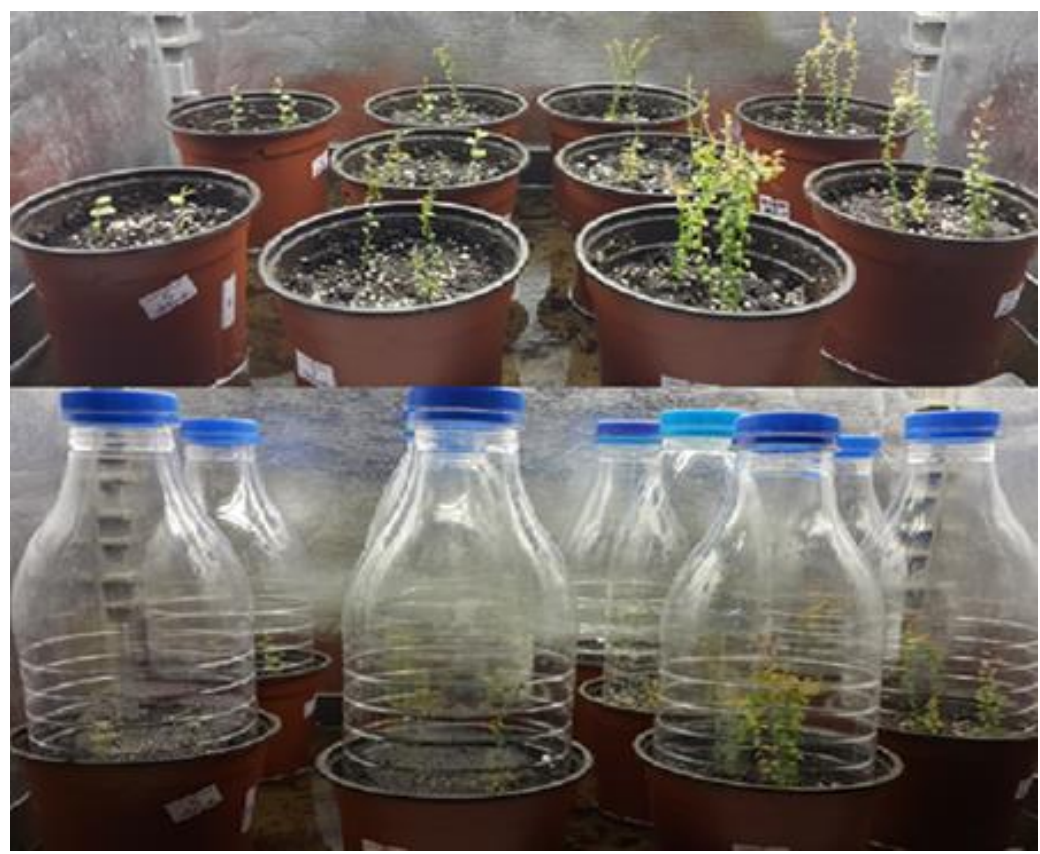

Рисунок 6 - Адаптация растений-регенерантов V. corymbosum сорта Блю Берри

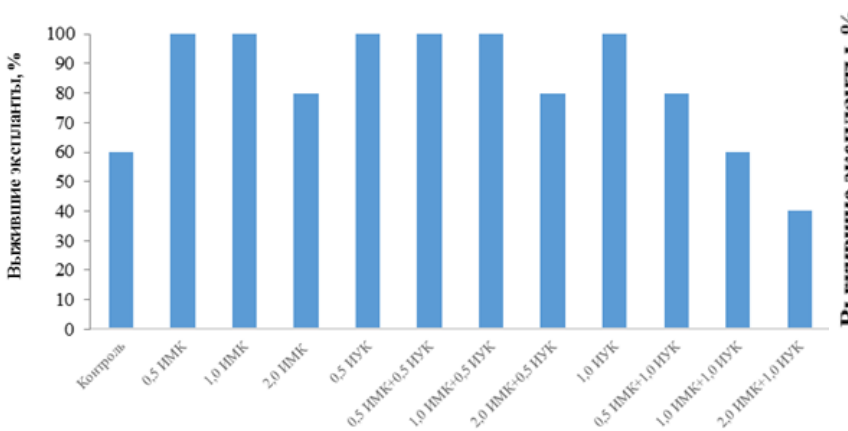

Рисунок 7 - Влияние различных концентраций ауксина на выживаемость растений-регенерантов V. corymbosum сорта Блю Берри



Рисунок 8 - Влияние различных концентраций ИМК на выживаемость растений-регенерантов V. corymbosum сорта Блю Берри, не имеющие корневой системы на этапе акклиматизации 


\section{Список литературы:}

1. Mainland C., Tucker J. Blueberry health information-some new mostly review // VII International Symposium on Vaccinium Culture. 2000. P. 39-43.

2. Zu X.Y., Zhang Z.Y., Zhang X.W., Yoshioka M., Yang Y.-N., Li J. Anthocyanins extracted from Chinese blueberry (Vaccinium uliginosum L.) and its anticancer effects on DLD-1 and COLO205 cells // Chinese Medical Journal. 2010. Vol. 123. P. 2714-2719.

3. Matchett M.D., Mackinnon S.L., Sweeney M.I., Gottchall-Pass K.T., Hurta R.A. Blueberry flavonoids inhibit matrix metalloproteinase activity in DU145 human prostate cancer cells // Biochemistry and Cell Biology. 2005. Vol. 83. P. 637-643.

4. Пинчукова Ю., Масанский С. Пищевая ценность плодов голубики // Голубиководство в Беларуси: итоги и перспективы: мат-лы респ. науч.-практ. конф., 2012. С. 45-48.

5. Эрст А., Вечернина Н. Микроразмножение новых перспективных сортов Vaccinium uliginosum L. // Вісник Харківського національного аграрного університету. Серія: Біологія. 2010. С. 96-103.

6. Busby A.L., Himelrick D.G. Propagation of blackberries (Rubus spp.) by stem cuttings using various IBA formulations // VII International Symposium on Rubus and Ribes. 1998. P. 327-332.

7. Сидороич Е., Кутас Е. Клональное микроразмножение интродуцированных сортов голубики высокой и брусники обыкновенной в культуре in vitro в связи с генотипами // Вести АН Беларуси. Сер. «Биол. науки». Минск, 1998. С. 5-9.

8. Попович Е., Филипеня В. Влияние экзогенного цитокинина на жизнеспособность эксплантов голубики высокой in vitro // Физиология растений. 1997. С. 104-107.

9. Волотович А. Результаты деятельности НИЛ клеточных технологий в растениеводстве УО «Полесский государственный университет» как модель развития прикладной биотехнологии на базе вуза. 2011. С. 286-288.

10. Тихомирова Л. Получение стерильной активно пролиферирующей культуры ириса в условиях in vitro // Достижения науки и техники АПК. 2010. № 8. C. 37-39.

11. Lloyd G., Mccown B. Commercially-feasible micropropagation of mountain laurel, Kalmia latifolia, by use of shoot-tip culture. Combined Proceedings of the International Plant Propagator's Society. 1980. Vol. 30. P. 421-427.

12. Cuce M., Bektas E., Sormen A. Micropropagation of Vaccinium arctostaphylos L. via lateral-bud culture // Turkish Journal of Agriculture and Forestry. 2013. Vol. 37 (1). P. 40-44.

13. Cuce M., Sormen A. Micropropagation of Vaccinium myrtillus L. (Bilberry) naturally growing in the Turkish flora // Turkish Journal of Biology. 2015. Vol. 39 (2). P. 233-240.

14. Cuce M., Sormen A. In vitro production protocol of Vaccinium uliginosum L. (bog bilberry) growing in the Turkish flora // Turkish Journal of Agriculture and Forestry. 2017. Vol. 41 (4). P. 294-304.

15. Вечукнина Н.А., Таварткиладзе О.К., Эрст А.А., Горбунов А.Б. Ускоренное размножение голубики топяной in vitro // Вестник Алтайского государственного аграрного университета. 2008. № 6 (44). С. 21-25.

16. Cohen D. Application of micropropagation methods for blueberries and tamarillos // Application of micropropagation methods for blueberries and tamarillos. 1980. Vol. 30. P. 144-146.

17. Вечукнина А. Методы биотехнологии в селекции, размножении и сохранении генофонда растений // Бюллетень Ботанического сада-института ДВО РАН. 2004. № 12. С. 22-30.

18. Meiners J., Schwab M., Szankowski I. Efficient in vitro regeneration systems for Vaccinium species // Plant Cell, Tissue and Organ Culture. 2007. Vol. 89. P. 169-176.

19. Емельянова Е.П. Влияние ауксинов на укоренение in vitro сортов Vaccinium uliginosum L. // Известия Алтайского государственного университета. 2010. С. 25-28.

20. Сидорович Е.А., Кутас Е.Н. Клональное микроразмножение новых плодово-ягодных растений. Минск: Навука і тэхніка. 1996. 246 с.

\section{ROOTING OF VACCINIUM CORYMBOSUM L. MICROSHOOTS CV. «BLUE-BERRY» IN CULTURE IN VITRO AND EX VITRO}

(C) 2018

Mohamed Gamil Rayan Abuo El-Dis, postgraduate student of Botany and Plant Physiology Department

Khusnetdinova Landysh Zavdetovna, candidate of biological sciences, associate professor of Botany and Plant Physiology Department

Timofeeva Olga Arnoldovna, doctor of biological sciences, professor of Botany and Plant Physiology Department Kazan (Volga Region) Federal University (Kazan, Russian Federation)

Abstract. This paper discusses a method of micropropagation of Vaccinium corymbosum L. cv. «Blue-Berry». The results showed that WPM supplemented with $1,0 \mathrm{mg} / \mathrm{l}$ of zeatin in combination with $0,1 \mathrm{mg} / \mathrm{l}$ of indolyl-3butyric acid was more effective for the multiplication of blueberry axillary shoots. The maximum increase in the number of healthy axillary shoots was observed in the fourth subculture, whereas the phenomenon of hyperhydration (vitrification) began to appear in the fifth subculture. In addition, it was established that the presence of indolyl-3butyric acid and 1,0 g/l of activated charcoal in the nutrient medium lead to the development of good root system of the Vaccinium corymbosum cv. «Blue-Berry». The highest mean number of roots formed per explant was obtained on WPM medium, supplemented with $0,5 \mathrm{mg} / 1$ indolyl-3-butyric acid after 10 weeks. Acclimatization of in vitro regenerated plantlets of Vaccinium corymbosum with a developed root system in ex-vitro conditions ( $\mathrm{pH} 3,5-4)$ showed a $100 \%$ survival rate.

Keywords: Vaccinium corymbosum L.; highbush blueberry; regenerated plantlets; in vitro; ex vitro; explant; nodal segments; WPM medium; apical meristem; micropropagation; Blue-Berry variety; adaptation; rhizogenesis; rooting; biological resources. 